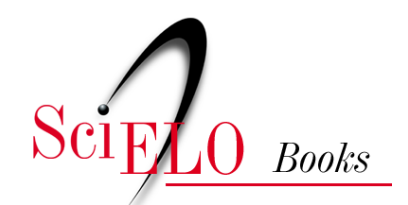

\title{
Capítulo 3 \\ O movimento de pobladores como movimento social urbano (1970-73)
}

\author{
Alexis Cortés
}

CORTÉS, A. O movimento de pobladores como movimento social urbano (1970-73). In: Favelados e pobladores nas ciências sociais: a construção teórica de um movimento social [online]. Rio de Janeiro: EDUERJ, 2018, pp. 115-172. Sociedade \& política collection. ISBN: 978-85-7511-477-3. https://doi.org/10.7476/9788575114773.0004.

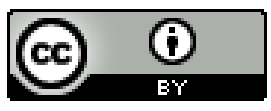

All the contents of this work, except where otherwise noted, is licensed under a Creative Commons Attribution 4.0 International license.

Todo o conteúdo deste trabalho, exceto quando houver ressalva, é publicado sob a licença Creative Commons Atribição 4.0.

Todo el contenido de esta obra, excepto donde se indique lo contrario, está bajo licencia de la licencia Creative Commons Reconocimento 4.0. 


\section{Capítulo 3 \\ O MOVIMENTO DE POBLADORES COMO MOVIMENTO SOCIAL URBANO (1970-73)}

O Chile de finais dos anos 1960 e começo dos anos 1970 era o epicentro de múltiplos processos. Se por um lado, a instalação, há quase duas décadas no país, de duas das mais importantes instituições de pesquisa latino-americana, FLACSO e CEPAL, já tinha atraído uma massa intelectual crítica excepcional, por outro, a intensa e acelerada aplicação de reformas sociais, iniciada primeiro com a Revolução em Liberdade do social-cristão Eduardo Frei Montalva (eleito em 1964) e aprofundada mais tarde com a eleição do socialista Salvador Allende (eleito em 1970), com sua "via chilena ao socialismo", tinha convertido o país num foco extremamente atraente para os pesquisadores que queriam compreender as mudanças que experimentava (BEIGEL, 2013; DEVÉS VALDÉS, 2004a).

O Chile, entre 1970 e 1973, experimentou um processo de "hiper-mobilização" da sua sociedade (LANDSBERGER e MCDANIEL, 1976), notadamente das suas classes subalternas: a classe operária, os camponeses e os pobladores. As cidades chilenas foram um verdadeiro laboratório da mudança social, sendo a maior novidade a consolidação do movimento de pobladores.

Dessa maneira, em Santiago do Chile, contagiado pelo clima de efervescência social e política reinante neste país, no começo dos anos 1970, um grupo de pesquisadores se dedicará ao estudo do que parecia ser um novo ator social potencialmente decisivo 
na polarização chilena da época: os pobladores. Estes intelectuais identificaram nos marginados (ou no lumpemproletariado) "uma ponta de lança urbana”, segundo a expressão de Fanon (2007), dos processos de transformação social que experimentava o continente.

Este capítulo visará precisamente mostrar quais foram as principais ideias e contribuições realizadas por este grupo de pesquisadores. Para tanto, mostrarei como um antecedente intelectual indireto a compreensão que Frantz Fanon fez do papel político do lumpemproletariado. Embora a tendência consolidada nas ciências sociais seja considerar o autor martinicano como um teórico da marginalidade radical, neste capítulo apresentarei argumentos que contradizem tal definição. Em contraste, o mostrarei não como um teórico da questão urbana, mas sim como o intelectual anticolonialista que influenciou profundamente uma série de cientistas sociais identificados com a esquerda radical, destacando como sua perspectiva política permite compreender alguns dos principais posicionamentos do grupo que nesse período fez do movimento de pobladores seu principal objeto de pesquisa.

Finalmente, me deterei na trajetória teórica do autor mais destacado deste grupo de pesquisadores, Manuel Castells, tentando mapear as principais transformações que experimentou seu pensamento urbano, com especial atenção no conceito que é mais caro a esta pesquisa: o de movimentos sociais urbanos.

\section{Os marginalizados como ponta de lança da transformação social: Frantz Fanon e a marginalidade}

Sem dúvida, entre os autores da teoria da marginalidade, existia uma tendência a associar o processo de urbanização nos países subdesenvolvidos com a radicalização e a violência política das camadas populares que, ao migrarem à cidade, não tinham satisfeitas as expectativas que a própria economia urbana gerava. Isto levará diferentes autores (SILVA e ZICCARDI, 1983; OLIVEN, 
1980) a considerarem a figura de Frantz Fanon como um dos mais lúcidos expoentes da visão de esquerda dessa teoria. Afirmação que se sustentava com a citação de uma passagem da famosa obra do autor martinicano, Os Condenados da Terra:

É nessa massa, nesse povo dos cordões de miséria, das casas 'de latão', no seio do lumpemproletariado onde a insurreição encontrará sua ponta de lança urbana. O lumpemproletariado, coorte de famintos destribalizados, desclanizados e radicalmente revolucionários de um povo colonizado. (FANON, 2007, p. 119).

Não obstante a frase citada sintetize magistralmente uma concepção do lumpemproletariado que chegará a ser hegemônica entre os intelectuais de esquerda que estudaram o fenômeno urbano durante o começo dos anos 1970, particularmente no Chile, resulta equívoco entender a produção de Fanon como a de um teórico da marginalidade. A preocupação do autor será o processo de descolonização do terceiro mundo, que estava em curso quando publicou Os Condenados da Terra, em 1961, e que transformou sua obra, segundo René Ménil, no "novo evangelho da libertação dos povos" (apud PIERRE-CHARLES, 2011, p. 51). Aliás, será o próprio processo de luta anticolonial que levará Fanon a refletir sobre o papel das diferentes camadas dos indígenas colonizados. Nesta análise, estará incluído o lumpemproletariado, mas não será ele o foco de seu raciocínio, e sim os camponeses.

Para Fanon, a chave da revolução anticolonial está nos camponeses, pois, na sua visão, a dicotomia urbano/rural parece reproduzir a diferenciação colonial/anticolonial. Tal como explica no texto, da perspectiva do mundo rural:

Os habitantes da cidade são 'traidores, vendidos', que parecem se levar bem com o ocupante e tratam de triunfar dentro do marco do sistema colonial... Estamos frente à clássica oposição entre o 
campo e a cidade. É a oposição entre o colonizado, excluído das vantagens do colonialismo e o que consegue tirar benefício da exploração colonial (FANON, 2007, p. 103).

Os camponeses são as principais vítimas do processo de colonização, já que o mundo rural não observa nenhum benefício da situação de colonização, pelo contrário, se vê constantemente ameaçado pela inserção de novas formas de vida que rivalizam com as tradições e os valores locais. Neste cenário, os operários aparecem como a fração do povo melhor acomodada e mais favorecida pelo regime colonial, já que o colonizador estaria ciente do papel estratégico do operariado para a continuidade do regime. Logo, não demoraria em "seduzir" esta camada popular, deixando-a numa situação de relativo privilégio. Os operários, porém, teriam algo a perder numa revolução anticolonial, por isso Fanon (2007, p. 100) chamará a atenção para o fato de que:

O grande erro, o vício congênito da maioria dos partidos políticos nas regiões subdesenvolvidas tem sido se dirigir, segundo o esquema clássico, principalmente às elites mais conscientes: o proletariado das cidades, os artesãos e os funcionários, ou seja, uma ínfima parte da população que não representa muito mais que um por cento.

Esta dessacralização do papel do proletariado na revolução anticolonial implicará uma valorização política de outras camadas populares, destacando os camponeses. Nesse contexto, o lumpemproletariado, esse setor que vive amontoado nos bairros miseráveis da periferia da cidade, será concebido como um grupo constituído principalmente por "camponeses sem terra" que tiveram que abandonar o campo pela sua condição de "bocas excedentes". Boa parte da revalorização política que Fanon faz do lumpemproletariado depreende-se da importância que outorga ao campesinato na luta 
contra a colônia. Essa ideia fica mais clara se citamos novamente a passagem completa do parágrafo referido no começo desta seção.

A insurreição, surgida do campo, penetrará nas cidades pela fração do campesinato bloqueada na periferia urbana, a qual não tem podido encontrar ainda um osso que roer no sistema colonial. Os homens obrigados pela crescente população do campo e a expropriação colonial a abandonar a terra familiar, perambulam incansavelmente pelas diferentes cidades, esperando que um dia ou outro se lhes permita entrar. É nessa massa, nesse povo dos cordões de miséria, das casas 'de latão', no seio do lumpemproletariado onde a insurreição encontrará sua ponta de lança urbana. $\mathrm{O}$ lumpemproletariado, coorte de famintos destribalizados, desclanizados e radicalmente revolucionários de um povo colonizado (FANON, 2007, pp. 118-9).

Esta concepção do lumpemproletariado como uma extensão urbana do campesinato presente em Fanon é próxima da visão da Teoria da Marginalidade, a qual pensava as formas de habitação marginais (favelas, callampas, tugúrios etc.) como um quisto rural na cidade. Mas, apesar desta relação ser um traço fundamental da Teoria da Marginalidade, esta convergência não é suficiente para considerar o autor como um expoente de esquerda da Marginalidade. São outros os debates, outras as bibliografias e outros os protagonistas na sua literatura.

Todavia, resulta interessante destacar que a valorização política do lumpemproletariado sobre a do papel de um proletariado em situação de privilégio, será recebida com particular sensibilidade por setores da esquerda radicalizada latino-americana (no final dos anos 1960), a qual incorporará essa ideia em sua práxis política como uma arma de disputa do mundo popular frente aos partidos de esquerda tradicionais (principalmente os Partidos Comunistas), extremamente influentes no proletariado urbano. 
Sem dúvida, a valoração política do lumpemproletariado realizada por Fanon é meritória, sobretudo se se considera a desconfiança que a esquerda tradicionalmente mostrou frente a esse setor. Porém, esse receio está presente, embora matizado, no próprio $\mathrm{Fa}$ non (2007, p. 125):

O colonialismo encontrará igualmente no lumpemproletariado uma massa considerável propícia para a manobra. Todo movimento de libertação nacional deve prestar o máximo de atenção, pois, a esse lumpemproletariado. Este responde sempre à chamada à insurreição, mas se a insurreição acredita que pode se desenvolver o ingnorando, o lumpemproletariado, essa massa de famintos e marginalizados, se lançará à luta armada, participará no conflito, mas do lado do opressor.

O perigo de que o lumpemproletariado vire reserva humana mercenária disponível para lutar do lado das tropas coloniais é o que leva Fanon a ser tão enfático quanto à necessidade de fazer um trabalho político conscientizador, por parte dos partidos nacionalistas, entre os membros desta camada. Aliás, o autor reconhece no lumpemproletariado um ator político que pode ser desequilibrante na luta de libertação nacional. Assim, um setor popular marginalizado, mesmo pela esquerda, cobra centralidade política na sua obra. Esta será só uma das ideias do autor que terão eco na intelectualidade da época.

Antes de ser uma obra sobre a marginalidade, Os Condenados da Terra é um manifesto anticolonial. E a contribuição desta obra para a Sociologia dos Pobres Urbanos parece ser mais um reflexo do clima intelectual da época de sua publicação (processo de descolonização, Revolução Cubana etc.) e, consequentemente, da influência que teve no campo intelectual de esquerda que, posteriormente, iniciou os debates sobre camadas populares urbanas. Já assinalou Karl Mannheim (1963) que a história do pensa- 
mento não é apenas uma história das ideias, mas também deve ser compreendida e analisada segundo os diferentes "estilos de pensamentos" desenvolvidos pelos diversos grupos sociais. Portanto, o desenvolvimento e exercício reflexivo dos intelectuais não pode ser separado do ambiente social e histórico no qual nascem, se desenvolvem, se fundem e desaparecem suas ideias. Frantz Fanon, para seguir utilizando uma metáfora mannheimniana, forma parte da constelação intelectual que deu origem ao pensamento que se desenvolveu no Chile no âmbito popular urbano.

Nesse sentido, a influência de Fanon sobre os intelectuais de esquerda (radical) foi gravitante nos projetos políticos que buscaram dar uma consistência orgânica à potencialidade dos marginais da cidade. Esta marca não estará dada apenas pelo papel do lumpemproletariado, mas também pela importância outorgada à violência no processo de unificação das lutas nacionais e populares: "Apenas a violência exercida pelo povo, violência organizada e aclarada pela direção, permite às massas decifrar a realidade social, lhe dá a chave dela" (FANON, 2007, p. 135). No caso do Chile, isto se apreciará no Movimento de Esquerda Revolucionária (MIR em espanhol), cuja práxis no mundo urbano popular atraiu parte importante da intelectualidade que elaborou a ideia de Movimentos Sociais Urbanos.

\section{Os Pesquisadores do CIDU}

O Centro Interdisciplinario de Desarrollo Urbano (CIDU), nascido como consequência da Reforma Universitária que experimentou a Pontifícia Universidade Católica do Chile em 1968, foi o principal grupo de pesquisa que articulou a produção dos autores que buscaram compreender o papel desempenhado pelos pobladores no processo de mudança social experimentado pelo país. Ante seus olhos se apresentava um movimento com características inéditas por sua massividade, combatividade e politização 
(PASTRANA e THRELFALL, 1974). Mais especificamente, este centro tentou compreender a novidade político-social que representava o movimento organizado a partir do estabelecimento de inúmeros campamentos ${ }^{1}$, originados por tomadas de terrenos dirigidas por militantes dos principais partidos políticos do país desde o centro até a esquerda (Partido Democrata Cristão, Comunista, Socialista e Movimento de Esquerda Revolucionária).

A primeira tarefa que esses pesquisadores tiveram foi demonstrar a falsidade das teses da teoria da marginalidade desaliana. Questionando a ideia de concentração de lúmpen associada às habitações marginais, os diversos estudos empíricos realizados por esses autores demonstraram a "heterogeneidade popular" do universo poblacional, na qual assume um lugar destacado, uma fração

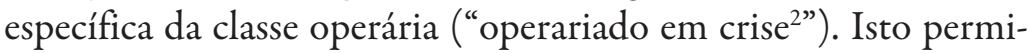
tiu, ao mesmo tempo, problematizar a ideia de subcultura marginal (ou "cultura da pobreza", segundo o já mencionado Oscar Lewis) e afirmar a existência de uma cultura nos bairros populares, mas que vive ao ritmo ideológico e político dos processos gerais da luta de classes na sociedade. Nas palavras do mais destacado desses autores:

As poblaciones não são o refúgio da desintegração social nem apresentam uma concentração de lúmpen, senão são a única forma possível de residência para uma fração da classe operária (aquela dos setores 'tradicionais') à qual se agregam uma boa parte do proletariado da grande indústria, e até empregados e pe-

1 Para Santa María (1973), o “campamento" é uma organização social e territorial e uma forma de crescimento não planejado do solo urbano que, nos anos 1970, representava a operação urbana de maior importância na cidade de Santiago, seja na forma de assentamento espontâneo ou na forma de tomada organizada.

2 Castells (1972) distingue entre a "aristocracia operária", que age de maneira economicista no âmbito poblacional e que é conduzida pelo PC, e o "proletariado em crise", politicamente radicalizado a partir da reivindicação urbana e conduzido pela esquerda revolucionária. 
quenos burgueses, embora os grupos operários sejam claramente hegemônicos. (CASTELLS, 1972, pp. 14-6).

Ao mesmo tempo, Castells criticará a lógica de intervenção da teoria da marginalidade elaborada pelo DESAL, enquanto doutrina orientada a fundamentar a práxis política do Partido Democrata Cristão (DC). A marginalidade se apresenta como uma tentativa de ocultar a relação de exploração, que seria o produto do tipo de integração de um regime capitalista, logo, as causas da marginalidade, que para o autor são econômicas, não podem se encontrar nas características próprias dos marginais (incapacidade organizacional ou subcultura). Ao mesmo tempo, com a doutrina desaliana se visa legitimar uma lógica de Estado paternalista e populista, onde se espera que os marginais virem clientes eleitorais desse projeto político.

Paralelamente, a crítica se estende à práxis dos partidos operários tradicionais (principalmente o Partido Comunista), constituídos majoritariamente por trabalhadores não marginais. Esses partidos desenvolveriam uma penetração no mundo popular de caráter economicista apenas reivindicativa. Assim, e devido à fraca penetração ideológica, existiria uma tendência a fortalecer as Juntas de Vecinos (JJVV) como um instrumento de disputa eleitoral. Ao analisar os diferentes níveis de consciência dos pobladores mediante uma tipologia de Alain Touraine, Vanderschueren (1971b) concluirá que, apesar dos esforços mobilizadores da esquerda tradicional, a evidência indicava que não se conseguiu desenvolver uma "consciência hegemônica" (projeto alternativo de poder) entre os pobladores, prevalecendo uma "consciência dependente" (colaboracionista ou que vê possibilidade de mudança apenas de cima para baixo), já que este setor político desenvolveu antes uma política de negação da influência democrata-cristã que uma afirmação da classe própria do setor poblacional. Assim, observava-se 
uma presença mínima de "consciência constituinte" (ou de caráter submisso).

Segundo esses autores, os campamentos eram, para a direita, o espaço de resguardo do lúmpen; para a esquerda operária (comunistas), o principal meio de pressão das massas para obter habitação; e, para a esquerda revolucionária, o primeiro passo para tomada do poder ("nos tomamos este sitio y luego el poder"). Além das interpretações em disputa, o CIDU reconhecia nos campamentos de pobladores uma experiência única de luta política e de organização urbana. $\mathrm{O}$ traço que dotará de originalidade este movimento é que o processo de tomada de terrenos estava fortemente vinculado à questão do poder, não apenas pela presença de organizações populares das mais variadas no interior dos campamentos, mas também pelo papel diretamente político exercido pelo ato da tomada de terreno e pelo processo político experimentado pelo Chile durante o período em que o movimento de pobladores ganha centralidade (finais dos 1960 e começo dos 1970), o que marcará a intervenção diferencial dos diferentes atores políticos nos campamentos (CIDU, 1972).

Para Castells (1972, p. 82), o que caracterizará o movimento de pobladores é a articulação, no marco da luta de classes, da reivindicação urbana e de uma estratégia política ligada à mobilização de objetivos baseados no governo local, o que permitiu o desenvolvimento de novas formas de organização política. Assim, serão três elementos que se fundirão para estabelecer o movimento de pobladores:

Uma forte reivindicação em torno à habitação e ao consumo coletivo em geral; o pertencimento a uma fração do proletariado inserida, em geral, em setores em crise ou de escassa geração de renda; a intervenção de conjunturas e linhas políticas fundamentalmente distribuídas em três tendências, que para simplificar, 
nomearemos como vinculada à Unidade Popular ${ }^{3}$, à esquerda revolucionária e à Democracia Cristã.

O que explicaria a centralidade, mesmo que por sobre a luta operária nas fábricas, da questão urbana nas lutas sociais, em Santiago, no período prévio à eleição de 1970 (na qual terminaria ganhando o socialista Salvador Allende), seria a coincidência tática de três estratégias políticas opostas que concorreram no específico espaço dos campamentos e poblaciones para dar uma saída à crise estrutural da habitação popular no Chile. A primeira destas estratégias é a representada pela Democracia Cristã (DC) que, inspirada na política de promoção popular, era considerada pelo CIDU apenas como uma tentativa populista de inclusão dos operários na sua clientela potencial, mediante a mobilização em torno de uma contradição secundária: a habitação. A segunda era representada pelos partidos operários, notadamente o Partido Comunista, os quais tentavam levar a batalha política ao terreno proposto pela $\mathrm{DC}$ visando à campanha eleitoral de 1970. Finalmente, a esquerda revolucionária liderada pelo Movimiento de Izquierda Revolucionaria (MIR), que achou no caráter explosivo das tomadas uma fonte fecunda para alimentar sua estratégia de luta armada, assim como uma chance para penetrar nos setores operários e populares que no mundo sindical eram hegemonizados pelos comunistas e socialistas. Nessa disputa, o tipo e o nível de vinculação dos campamentos à luta política dependerão das características da organização política dominante no campamento. E, embora nos textos do CIDU se evidencie uma preferência pelas estratégias revolucionárias e extrainstitucionais, eles encontraram nos campamentos uma fonte de transformação social diversificada e com enorme capacidade criativa para intervir em diferentes frentes (justiça, produção, consumo coletivo, cultura etc.).

3 Coligação que apoiava o governo Allende. 
Outros autores que também formavam parte do CIDU destacaram como a mobilização do setor poblacional e suas reivindicações urbanas geraram novas formas de "poder popular", outorgando um novo caráter à luta política chilena (QUEVEDO e SADER, 1973). Os pobladores foram capazes de se organizar de tal maneira que conseguiram, em boa parte, suprir o Estado quando este não era capaz de satisfazer as demandas populares. A base do que seria o "poder popular" é a capacidade de opor às instituições vigentes outras instituições alternativas, sendo o exemplo que mais chama a atenção dos autores a experiência de justiça popular dada por formas de autoadministração de disciplina, ordem e segurança dentro dos campamentos.

Contudo, eles reconheciam nas diversas manifestaçóes de poder popular sentidos políticos diferentes e estavam cientes de que se elas se restringissem ao nível reivindicativo, perderiam capacidade de transformação. Por isso, advertiam que o movimento deveria desenvolver uma visão global que as unificasse. Porém, o caráter inovador dessas práticas sociais, pela forma qualitativamente diferente de enfrentar os problemas e as carências dos setores populares, configurava uma tentativa original dos dominados para mudar a natureza da situação de subordinação na qual se encontravam, visando uma posição hegemônica dentro da sociedade para sua classe.

Coerentemente com o dito até aqui, uma das experiências que mais reflexão gerou, entre os pesquisadores do CIDU, foi a Justiça Popular ensaiada no Campamento Nueva La Habana. O interesse, neste caso, era duplo: a ideia de uma Justiça Popular foi considerada, por uma parte desses pesquisadores, como a principal inovação do movimento e como a expressão mais clara do poder popular em construção; por outra parte, Nueva La Habana foi identificado como o campamento modelo do MIR tanto por seu nível de organização quanto pelo seu grau de consciência política. Este último se pode apreciar em algumas das declarações das 
lideranças do campamento no documento "Organización y lucha poblacional en el proceso de cambios: la experiencia del campamento Nueva Habana", publicado em 1972:

O mais importante de tudo isto é que se crie uma consciência política nos companheiros que lhes permita visualizar seus inimigos fundamentais, e quais devem ser suas metas: basicamente, a tomada do poder junto com os trabalhadores. É por isso que temos a obrigação de que cada um destes comitês sem casa - que logo se transformarão em acampamentos - se tornem um meio de poder, através de suas próprias organizações, tais como: sua própria organização de vigilância, de cultura, de saúde, de construção, etc., para incorporar o poblador ao processo [...] A única solução que têm as massas trabalhadoras para obter suas reivindicações é por meio da tomada do poder total (apud PASTRANA e THRELFALL, 1974, p. 85).

Nueva La Habana nasceu em outubro de 1970 como resultado da transferência, a um terreno cedido na comuna de $\mathrm{La}$ Florida, de famílias que tinham participado de três tomadas de terrenos organizadas pelo MIR, partido que rapidamente apostou em transformar esse campamento na experiência mais avançada de sua política poblacional. Nueva La Habana se destacou pelo seu elevado grau de organização interna e de mobilização nas diversas tarefas designadas pelo MIR na luta política nacional.

Foi em consideração a essa exemplaridade que Jorge Fiori (1973a) realizou seu estudo sobre a experiência de autoadministração de Justiça nesse campamento, onde tentou traçar as potencialidades e limitações do processo de Justiça Popular experimentado pelos pobladores de Nueva La Habana. Nesse bairro popular, para o autor, estariam se estabelecendo as bases de uma sociedade futura, sendo, em particular, a experiência de autoadministração de justiça um embrião de uma nova justiça de caráter popular. 
Uma das primeiras medidas do MIR na frente poblacional foi a criação das "Milícias Populares", como uma forma de estabelecer um vínculo orgânico entre o partido e a frente de massas e, ao mesmo tempo, como o principal instrumento para dirigir os pobladores e para organizar a defesa frente à repressão policial. A conquista de um teto mediante um ato ilegal exigia a contraposição de normas próprias, assim como de disciplina e organização, correspondendo às milícias o papel mais importante no autodisciplinamento dos pobladores. Da necessidade de manter um grupo humano disciplinado e coeso é que surge como efeito secundário, segundo Jorge Fiori, a experiência no plano da justiça. Os pequenos furtos, as brigas entre vizinhos, os conflitos familiares, a existência de pontos clandestinos de venda de álcool, eram condenados não como comportamentos desviados em si próprios, mas como ameaças às perspectivas de sobrevivência do grupo e da continuidade da luta. Assim, esses comportamentos se tornam matéria de conscientização política.

Uma vez diluída a possibilidade de repressão, pelo reconhecimento do governo Allende, adicionando alguns inconvenientes de organização interna e de desorientação política, a existência de milícias perdeu sua razão de ser, e estas desapareceram a começos do ano de 1971 no campamento. Será majoritariamente com ex-integrantes das milícias que se conformará a Comissão de Disciplina restituindo a discussão de uma ideia de justiça popular, desta vez orientada ao caráter reeducativo das medidas tomadas em relação a quem violasse algumas das normas do campamento. Um dos castigos, por exemplo, era a leitura dos clássicos do marxismo como forma de reeducação e conscientização do poblador sancionado. Jorge Fiori (1973a, p. 92) descreve essa Comissão como uma espécie de aparato controlador responsável por reunir antecedentes de cada caso, informar às instâncias correspondentes e assegurar o cumprimento das sanções. Este processo não se fará sem contradições, pois na prática a Comissão virou uma espécie de polí- 
cia local: "Produz-se assim um progressivo distanciamento entre a Comissão de Disciplina e o resto da organização e um crescente vazio entre sua ação concreta e o sentido geral que queria dar à ação da justiça”. Contradições que levaram finalmente à extinção desta Comissão e que estarão presentes também na conformação do Frente de Vigilância do campamento, instância diretamente vinculada a tarefas mais repressivas.

$\mathrm{O}$ caso que mais tensionou a experiência de justiça popular neste bairro foi o estupro, por parte de um operário, de uma das professoras da escola autogestionada pelos pobladores, pois os deixou na disjuntiva de aplicar justiça (e castigo) pelas próprias mãos ou deixar o caso nas mãos da justiça penal, ou seja, na justiça burguesa. A posição hesitante das lideranças do MIR também contribuiu a que a situação escapasse do controle das autoridades do campamento. Embora finalmente o acordo foi entregar o acusado à Justiça ordinária, no campamento, gerou-se, segundo Fiori, um importante debate sobre as nuances e diferenças entre a justiça popular e a justiça burguesa.

Para Jorge Fiori (1973, p. 99), o mérito desta situação residia no fato de a justiça popular se apresentar como um problema de poder, mas que para se realizar e alcançar suas potencialidades deveria transcender as limitadas fronteiras do campamento, uma vez que "as possibilidades de seu desenvolvimento enquanto embrião de uma nova justiça estão dadas justamente por um professivo vínculo - anunciado na experiência vivida e por sua vez provocada por ela entre a experiência pontual e a luta geral da classe trabalhadora pela tomada do poder".

Pastrana e Threlfall (1974), num livro aparecido pouco tempo depois do golpe de Estado, destacarão a contribuição do Movimento de Pobladores na luta política no marco da cojuntura dada pelo governo Allende. Eles salientarão que as tomadas de terrenos não foram a única forma usada pelo Movimento de Pobladores, 
aprofundando em outras duas: a organização em torno do abastecimento e os comandos comunais.

Se a tomada de terreno foi a principal ação coletiva do movimento entre 1970 e 1971, durante o ano de 1972 começa a crescer a organização do abastecimento por parte das camadas populares ante o aumento da inflação, a aparição do mercado negro e a política de desestabilização e desabastecimento promovida pela oposição. Assim, esta forma de organização terá seu ponto alto na paralização patronal de outubro de 1972, permitindo mobilizar setores mais amplos que os campamentos radicais e transformando-se, durante 1973, na principal expressão da luta de classes no frente poblacional, segundo esses autores.

As organizações populares de abastecimento começam a se reproduzir com a criação, por parte do governo Allende, das Juntas de Abastecimiento y control de precios (JAP). As duas tarefas fundamentais das JAPs eram, primeiro, a vigilância contra a especulação e o açambarcamento e, segundo, a organização do abastecimento e a distribuição dos produtos de consumo básico. As JAPs foram organizadas a nível local, segundo uma pauta estabelecida pelo governo que determinava a inclusão de lideranças territoriais das principais organizações locais. O governo da Unidade Popular identificou nas JAPs a forma politicamente mais adequada para amortecer a política inflacionária e conseguir controlar o preço dos produtos.

Para Pastrana e Threlfall, estas organizações tinham a novidade de trazer para o âmbito territorial a luta econômica da classe operária contra os efeitos da inflação crônica, a qual anteriormente só se realizava através da reivindicação salarial no lugar de trabalho e também mediante a pressão no Congresso. Porém, eles também identificaram como principais limitações desta experiência a incapacidade das JAPs para superar sua origem burocrática e verticalista, com exceção das Organizações de Abastecimento Direto 
e dos Almacenes del Pueblo desenvolvidos nos campamentos mais organizados e radicalizados.

A criação dos Comandos Comunales, desde mais ou menos um ano e meio antes do Golpe de Estado, foi a resposta popular dos partidos de esquerda à política de desestabilização gerada pela oposição ao governo Allende. Pastrana e Threlfall a qualificaram como um salto qualitativo na luta pelo poder político desenvolvido pelos movimentos sociais no contexto de agudização da conflitividade entre o mundo popular, o Estado e a burguesia. Os autores destacaram como traço destes Comandos: a vinculação orgânica e política, mesmo que irregular, entre pobladores e movimento operário; a criação de organismos locais de "poder popular"; a superação dos enquadramentos particulares que levavam cada organização popular à mobilização, pois os Comandos Populares respondiam a objetivos mais gerais, não relacionados diretamente com um problema específico de cada grupo. Concretamente:

A coordenação entre as diferentes frações da classe explorada mediante a centralização de suas reivindicações sob um organismo que assumisse a defesa do conjunto de seus interesses de classe; que aquilo fosse sobre uma base territorial, partindo de limites reduzidos, tais como os da comuna ou um setor dela, a fim de que, mediante a combinação desses dois elementos, se conseguisse exercer um poder local, um poder de massas que se levantaria como paralelo ao poder institucional e começaria a impor seus interesses sobre os da burguesia, criando uma dualidade de poderes, base da destruição do poder estatal burguês (PASTRANA e THRELFALL, 1974, p. 18).

Assim foi como começou a se organizar uma série de assembleias em diferentes frentes e organizaçóes que normalmente agiam de maneira separada, tais como um sindicato ou uma JAP começam a se comunicar, intercambiar experiências e se vincular 
organicamente. As organizações sociais com base territorial começam a se ocupar das principais ameaças que sofria o governo à sua continuidade: na área da produção, os Comandos se asseguram que as fábricas não paralisem mesmo sem técnicos; nos bairros populares, se estende a relação direta com as distribuidoras estatais de alimentos e com as indústrias para conseguir a entrega dos produtos mais básicos para a população. As dificuldades geradas pela inflação, o mercado negro e o desabastecimento geraram coordenações inéditas entre operários, pobladores e mesmo camponeses. Os autores também salientaram a capacidade desses Comandos para pressionar o Estado, não nos termos tradicionais de satisfação de necessidades, mas exigindo sua intervenção no sistema produtivo e distributivo em função dos interesses populares.

Porém, do ponto de vista político, a estratégia social da Unidade Popular se centrava na frente sindical com a nomeação de interventores públicos nas empresas e com a criação da Área Econômica de Propriedade Social, onde se vivenciava a luta mais aguda com a burguesia local. Isto contribuiu para enfraquecer a ligação entre as reivindicações de consumo massivo da frente poblacional com as da frente sindical. As demandas do movimento de pobladores apareciam assim como mais secundárias ainda: o próprio fato da demanda por habitação ser dirigida contra o Estado e não contra o setor privado retirava apoio político entre os aliados da esquerda, por serem consideradas demandas que enfraqueciam o governo.

Ao mesmo tempo, Pastrana e Threlfall reconheceram neste ponto uma capacidade diferenciada dos pobladores para evidenciar o caráter de classe do Estado, mesmo com a Unidade Popular no poder. Assim, a prevalência de uma opção pela Paz Social e não pela agudização das contradições fez com que se desapreciasse este tipo de instâncias de "poder popular", onde os campamentos mais radicalizados conseguiam influenciar com mais força o posicionamento político das forças de esquerda: "essas classes e frações 
de classe principalmente mobilizadas no movimento poblacional, nos Cordones Industriais e Comandos Comunales não se transformaram na ponta de lança de uma estratégia política diferente à que predominou no seio da UP" (PASTRANA e THRELFALL, 1974, p. 152). Efetivamente, como para muitos autores da época, o erro do governo da Unidade Popular nas análises sobre os pobladores era identificado com o fato de não impulsionar ou, ao menos, não optar por uma estratégia de construção de poder popular que fortalecesse e aprofundasse o processo de transformação social em curso.

Na descrição do Movimento de Pobladores realizado pelo CIDU parece existir uma simbiose entre este novo movimento e a estratégia política desenvolvida pelo MIR, que, a finais dos anos 1960 , tentou disputar a hegemonia do movimento popular com os partidos operários (PC e PS). Aliás, a tática das tomadas de terrenos (em muitos casos também propiciadas pela DC) se veria favorecida pela identificação do MIR com a medida, pelo caráter de ação direta, oferecendo, à disposição dos pobladores, o aparato paramilitar do grupo para enfrentar a repressão. A tomada parecia também justificar a necessidade imediata da luta armada defendida pelo MIR. Paralelamente, também o MIR assegurava sua penetração no movimento popular, injetando doses de massividade à sua estratégia política. Em especial, sua inserção no mundo poblacional lhe permitia disputar parte importante da massa operária num campo não hegemonizado pelos partidos operários, como acontecia nas fábricas e nos sindicatos. Serão os campamentos organizados pelo MIR os que concentrarão a atenção destes pesquisadores, que reconhecerão, na tentativa de criar microcomunidades revolucionárias, um salto qualitativo no movimento poblacional (CASTELLS, 1972).

As diferentes intervenções realizadas por atores externos (partidos) nas poblaciones de Santiago, por outra parte, são vistas por Vanderschueren (1971a) como ações que num extremo têm 
por objetivo neutralizar e controlar a pressão popular (pela política de Promoção Popular) e, no outro extremo, estimular a mobilização popular, visando à liberação "real" destes setores populares. $\mathrm{O}$ autor tomará partido por esta última perspectiva, a via mobilizante, que será entendida da seguinte forma:

A mobilização popular implica essencialmente coesionar os dominados - neste caso os pobladores - em torno de seus verdadeiros interesses de classe os fazendo perceber através de uma práxis adequada o sistema sócio-económico como fonte de exploração. É essencialmente uma tarefa de educação política destinada a fazer tomar consciência de seu próprio poder às forças populares fazendo delas a base de apoio de uma alternativa de poder na qual os dominados de ontem sejam os imperantes. (VANDERSCHUEREN, 1971b, p. 68, grifo nosso)

Embora a produção intelectual do CIDU sobre o movimento de pobladores tenha mostrado regularidades e coincidências, não se deve compreendê-la como um pensamento unificado. A constituição deste centro de pesquisa se caracterizou não apenas pela interdisciplinaridade, como nele também conviveram diversas visões políticas e urbanas. Vale lembrar que o próprio Roger Vekemans foi parte dos diretores/fundadores do centro. Mesmo no departamento que desenvolveu a perspectiva mais coesa sobre os pobladores, o Equipo de Estudios Poblacionales, existiam divergências. Uma interessante polêmica foi iniciada por José Luis Fiori a partir de uma leitura crítica do citado texto de Castells sobre $E l$ Movimiento de Pobladores y La Lucha de Clases. Para ele, as novas Teorias Poblacionales, desenvolvidas principalmente no CIDU, não tinham superado completamente as dívidas teóricas deixadas pelas perspectivas da marginalidade. Os novos autores teriam caído num estagnamento acrítico devido a que experimentavam um 
momento extremamente demandante em termos práticos pela intensa politização das poblaciones periféricas.

Os pesquisadores do Movimento de Pobladores, da mesma maneira que os teóricos da marginalidade, não teriam sido capazes de definir de forma precisa e homogênea o objeto de estudo, pelo qual seria difícil formular uma teoria coerente ou um conceito adequado do fenômeno estudado. José Luis Fiori (1973b, p.2) perguntava:

O que têm em comum a proliferação de poblaciones periféricas, a promoção massiva de organizações locais por parte do Estado, a multiplicação conjuntural das tomadas de terrenos e o nascimento de organizações populares de caráter comunal, para responder a problemas de fornecimento ou de defesa da Área Social da economia? E, se existe, qual é o fato que reúne estes fenômenos sob um mesmo conceito?

A concentração dos esforços reflexivos nas poblaciones periféricas e nas práticas organizativas que crescem no interior delas, para o referido autor, não seriam suficientes para comprovar que estes bairros formariam unidades homogêneas de análise, pois os resultados das próprias pesquisas mostrariam precisamente a heterogeneidade delas. Os objetos de análise não se corresponderiam com os objetos reais nem com discursos teóricos coerentes. Assim, por exemplo, o conceito de "universo poblacional" de Castells seria uma espécie de reencarnação do conceito de "mundo marginal", que teria como finalidade homogeneizar o objeto de estudo. $\mathrm{O}$ movimento de pobladores abarcaria, nessa lógica, todo o relacionado com a organização e a politização do velho mundo marginal.

Além do mais, mesmo o conceito de "proletariado em crise" seria uma ficção sociológica e política, usada para caracterizar os campamentos dirigidos pelo MIR, a partir de uma diferença esta- 
tística pouco significativa entre desempregados e operários qualificados dentro de um campamento modelo:

Esta conclusão se evidencia apenas com uma porcentagem mais elevada de desempregados encontrada no campamento Nueva La Habana, e outro de maiores ingressos encontrado no acampamento Bernardo O'Higgins. Com este instrumento na mão, o autor esboça uma tipologia dos outros acampamentos estudados. Constata-se, então, que o núcleo interpretativo funciona apenas nos casos dos acampamentos MIR e PC e mais precisamente nos casos considerados na construção do próprio núcleo. Isto é, o núcleo interpretativo apenas interpreta a si mesmo e a tipologia é só uma descrição apressada de quatro acampamentos 'modelos' (FIORI, 1973b, p. 21).

Outra crítica importante realizada por José Luis Fiori é que a caracterização do Movimento de Pobladores a partir da contradição secundária relacionada com habitação e equipamentos coletivos, que cumpriria o papel de ser o fator dinamizador do movimento e delimitador do universo poblacional, não é um problema comum a todas as unidades residenciais e organizações locais estudadas. Assinala o autor (1973b, p. 19): "mal poderiamos querer, então, reunir dentro de um mesmo pacote Tribunais Populares, Comitês 'Sem Casa', Centros de Mães, etc. Castells parece esquecer seu Universo e seu Movimento, ao discutir a organização de sua Vanguarda". O movimento até poderia ter nascido pela reivindicação de habitação, mas na prática não seria essa a variável que explicaria sua existência.

Por outra parte, o que os autores, como Castells, compreendiam como Movimento de Pobladores correspondia apenas a uma fração minoritária do hipotético mundo poblacional, a qual se identificava com uma linha política específica, a do MIR: "Para certos autores marxistas, porém, o desejo de valorização de uma 
frente de massas entendida, os têm levado a transformar incorretamente esta frente partidariamente justificável, num grupo social e político autônomo" (FIORI, 1973b, p. 28).

Efetivamente, por um lado, esse grupo de pesquisadores fez importantes contribuições para superar a concepção do movimento de pobladores apenas como um auxiliar do movimento operário, lhe outorgando um status político diferenciado, enquanto setor potencialmente decisivo na hora de resolver a polarização política experimentada pela sociedade chilena durante o governo Allende. Por outro, a discussão teórica sobre o movimento de pobladores que propunham refletia as disputas políticas da época no próprio campo intelectual. Em um momento de extrema divisão no interior da esquerda, esses autores tomaram posição a favor de uma estratégia e de um sujeito: a esquerda revolucionária e os pobladores. Com isso, se sobredimensionou o alcance e o papel do movimento de pobladores ligado à esquerda radical. A acentuada preocupação pela novidade que o movimento apresentava no marco da conjuntura do governo Allende fará com que esses autores percam de vista o processo de conformação como sujeito do próprio movimento previamente. Isso explicará a ausência de análise de experiências anteriores do movimento de pobladores, como a tomada de terrenos da población La Victoria, de 1957, acontecimento considerado por alguns autores como o fato que inicia o próprio movimento (GARCÉS, 2002). La Victoria, neste caso, ficará fora do interesse desses pesquisadores, em parte por estar associada à estratégia poblacional do Partido Comunista, a qual era identificada como uma práxis eleitoreira e economicista, apesar de que, em La Victoria, se anteciparam repertórios de ação coletiva que serão lidos como novidade nos anos 1970 (CORTÉS, 2014).

Porém, é preciso lembrar que o grupo que pesquisou o movimento de pobladores, no curto período que durou o governo Allende, se deparou com uma situação de mudança constante, grande mobilização e extraordinários níveis de organização e par- 
ticipação popular. Teria sido muito difícil para qualquer grupo de cientistas sociais registrar todos esses fenômenos, teorizá-los e, ao mesmo tempo, fazer as conexões históricas correspondentes. Os movimentos sociais no período da Unidade Popular sempre iam mais rápido nas suas dinâmicas, ações e repertórios que a capacidade dos pesquisadores de processá-los.

Por isso, não deveria estranhar que, apesar de ressaltar a importância das contradições no âmbito urbano, a luta dos pobladores, independentemente de sua valoração como um intento original de transformação da natureza da situação de subordinação na qual estes se encontravam, será conceitualizada em termos de consumo (notadamente habitacional). Não há, entre estes autores, pelo menos nos textos publicados na revista EURE, uma valoração específica da importância do espaço para a configuração das contradições sociais e nos desdobramentos dos movimentos sociais. Será preciso esperar até a publicação, em 1972 (primeira edição em francês), de A Questão Urbana de Castells (2008), para ver um esforço sistemático de teorização da variável espaço no contexto da mobilização urbana.

Porém, é preciso consignar que, se teve um autor que ofereceu uma leitura a contracorrente das interpretações dominantes na época, esse foi o sociólogo cubano-americano Alejandro Portes, a partir de sua pesquisa de doutorado, realizada no Chile, no final da década de 1960. Portes (1972) propôs uma teoria da racionalidade do slum oposta à teoria da marginalidade e às perspectivas que viam no movimento de pobladores uma comprovação do radicalismo associado a este tipo de habitação popular. Ambas as interpretaçôes partiam da definição da população do slum como culturalmente primitiva e, portanto, irracional: os pobres urbanos se debatiam supostamente entre a apatia e a tendência à radicalidade. O pobre seria radical porque é atrasado culturalmente e porque é governado pelo impulso, sendo incapaz de antecipar uma sequência de comportamentos orientados à obtenção de um deter- 
minado objetivo. Os pobres são dominados pela frustração e pelo primitivismo.

Segundo Portes (1969), as teorias do slum cometiam o erro de transformar condições sociológicas (pobreza) e físicas (moradia popular) em disposições psicológicas, imputando às vítimas características distorcidas dos seus vitimários. Assim, ele se dará a tarefa de desmitificar vários dos princípios dessas teorias com um forte respaldo empírico. Mediante a realização de vários surveys, o autor mostrará que as poblaciones estavam longe de ser o último refúgio frente à miséria de uma população recém-chegada à cidade sem capacidade de adaptação e de abrir caminho por si própria. A grande proporção de moradores não era migrante, tinha nascido em Santiago ou morava já há tempo na cidade, mostrando níveis de ingressos maiores que o esperado. Por outra parte, a habitação popular, mesmo precária, oferecia uma promessa de estabilidade futura e de inserção urbana no presente. Os pobladores se mostravam interessados na sua integração estável à estrutura urbana, para tanto, participavam de organizações de vizinhança e cultivavam aspirações sobre seu futuro e confiança no seu logro.

Outro equívoco, para Portes (1971), é compreender o slum como uma unidade homogênea. Não apenas a população que os habita é heterogênea, como é possível diferenciar tipos de habitação popular. O cubano-americano vai propor uma tipologia a partir de dois critérios: a origem do agrupamento urbano no passado e a orientação dos seus habitantes em relação ao futuro do agrupamento. Assim, slums criados por iniciativa popular ou governamental, por um lado, e os definidos como transitórios ou permanentes, por outro, geram dinâmicas organizacionais e uma relação entre poblador e espaço totalmente diferentes: o cruzamento entre iniciativa popular e transitoriedade originam os slums degradados; iniciativa governamental e transitoriedade, os projetos habitacionais decaídos; iniciativa popular e permanência, as poblaciones; e as iniciativas governamentais permanentes, as poblaciones urba- 
nizadas. São estas duas últimas as que apresentam maior grau de organização e de compromisso com o bairro, enquanto os tipos transitórios apresentam maior desapego e menor progresso.

Particularmente interessante é a visão sobre as poblaciones originadas por tomadas de terrenos. Portes (1971) reconhece que muitas delas foram originadas por uma bem sucedida agitação de militantes com fins ideológicos, mas para a maior parte dos invasores a tomada, mais que uma ruptura, era a única alternativa disponível para a conquista de um teto e seu primeiro e último confronto com a ordem estabelecida. Assim, uma vez estabelecidos, embora possam manter suas simpatias pela esquerda, o que tende a primar é sua intenção de integração à sociedade urbana através da posse segura de um pedaço de terra. O que Portes (1970) pretende mostrar é que não existe uma relação linear entre status econômico (ingresso-educação) e radicalismo de esquerda. Não é a condição de pobres nem sua precária situação o que faz dos pobladores atores manipuláveis em favor de projetos revolucionários. Embora o autor reconheça que a origem social (classe) é politicamente relevante como grupo de referência, é a identificação subjetiva com a classe que pode levar ao radicalismo. Uma situação de privação econômica pode originar explicações individualistas ou imputações estruturais sobre a origem da mesma. Logo, o esquerdismo radical pode estar presente nas poblaciones, porém mais por uma questão subjetiva que estrutural.

A tomada de terrenos, assim como, em geral, a conduta social dos moradores dos slums, é para Portes (1972) o produto de sequências calculadas de ações que buscam concretizar fins realistas. Tanto a participação como a não-participação se dão em função de considerações racionais utilitárias. As organizações de vizinhos ou comitês de sem-teto podem ser instrumentos válidos para serem empregados quando for necessário. $\mathrm{O}$ comportamento dos pobladores, assim como o das pessoas em geral, considera os modos mais eficientes de melhoramento de suas posições em relação aos 
limites e as barreiras presentes na sua sociedade. Particularmente o Chile de finais dos anos 1960 e começos dos 1970 era especialmente propício para que iniciativas como as tomadas e as organizações populares representassem uma das formas mais eficientes de integração dos pobres urbanos à sociedade chilena.

Porém, a mesma situação de polarização política da sociedade chilena, assim como o clima intelectual da época que exigia dos intelectuais posicionamentos em relação às mudanças em curso, eram ambientes pouco propícios para a recepção das ideias deste autor. Para além das suspeitas que devem ter existido no campo frente a sua condição de cubano-americano, sua matriz teórica weberiana, assim como suas conclusões que questionavam a existência de um movimento de pobladores radical, postergaram sua figuração no campo acadêmico chileno (nem tanto nos Estados Unidos), embora muitas das suas advertências tenham sido incorporadas nas análises críticas do movimento de pobladores depois do golpe de Estado.

Aliás, nenhuma crítica foi tão avassalante em relação às perspectivas defendidas pelo CIDU como o próprio desenrolar dos acontecimentos que levaram ao Golpe de Estado do General Pinochet, e que não apenas significaram o fim do processo ascendente de lutas e mobilização dos pobladores, como também o início de uma das repressões mais sistemáticas vistas contra movimentos sociais na América Latina. A Ditadura Militar perseguiu os partidos de esquerda organizados nos diferentes âmbitos da vida social: nos sindicatos, no campo, nas universidades e nas poblaciones e campamentos. O movimento de pobladores identificado com estes partidos sofreu um alto grau de repressão tanto de uma maneira seletiva, com a morte e desaparecimento de suas principais lideranças, quanto coletiva, com as invasões policiais, cercos de poblaciones, detenções massivas, sequestros, destruição e roubo de objetos pessoais e domésticos, segundo assinalou o Comité de Memoria Histórica da Corporación José Domingo Cañas (2005). 
Com o desaparecimento dos partidos e de suas lideranças, ao menos inicialmente, o movimento parecia ter também desaparecido. Algo similar aconteceu com a temática poblacional no âmbito acadêmico: o CIDU foi reestruturado, alguns dos seus pesquisadores tiveram que sair do país e a maior parte terminou por abandonar o estudo deste sujeito social aparentemente em extinção política. A revista $E U R E$ foi reorientada a outras temáticas do âmbito urbano e o produtivo ciclo de produção teórica sobre esse movimento chegou ao fim. Porém, Manuel Castells continuou refletindo sobre este e outros temas urbanos, tendo como principal objeto de pesquisa o que ele chamou de Movimentos Sociais Urbanos. Categoria que sofreu uma série de transformações e que teve que ser reformulada depois do final trágico do que seria o modelo por excelência da definição feita por este autor. Isso é o que analisaremos a seguir.

\section{A metamorfose do pensamento urbano de Manuel Castells e os Movimentos Sociais Urbanos}

A trajetória intelectual de Manuel Castells e o Movimento de Pobladores estão estreitamente ligados, não apenas pela influência que esse autor teve entre os pesquisadores do mundo poblacional durante sua passagem pelo CIDU no Chile a começos dos anos 1970, mas principalmente porque o conceito de Movimentos Sociais Urbanos, uma das categorias que mais impacto teve na questão urbana, durante muito tempo, ficou associada à experiência desenvolvida pelos pobladores durante o governo Allende, como realização histórica das potencialidades contidas nessa definição.

É no Chile da Unidade Popular, no seio do 'Movimento de Pobladores' que a ligação entre luta de classe, luta urbana e luta política tem sido estabelecida seguindo uma diversidade de situações e orientações nas quais a riqueza permite formular hipóteses em 
relação às condições sociais de articulação entre estes diferentes campos de contradições. (CASTELLS, 1973a, pp. 21-2).

Mesmo no texto mais importante de Manuel Castells sobre urbanismo, A Questão Urbana (2008), esta associação entre definição teórica e caso histórico pareceu ficar selada com a inclusão na edição em espanhol do artigo, anteriormente publicado na revista EURE, sobre "El Movimiento de Pobladores y Lucha de Clases" (CASTELLS, 1972). Porém, a derrota da experiência da Unidade Popular de Allende e, com ela, do Movimento de Pobladores que o autor e outros descreveram, obrigaram a uma revisão profunda do conceito de Movimentos Sociais Urbanos.

Efetivamente, o pensamento urbano de Manuel Castells e, mais especificamente, a ideia de Movimentos Sociais Urbanos experimentaram uma série de metamorfoses entre o começo dos anos 1970 e os anos 1980. Mais que uma autocrítica, a revisão do autor se aproxima a uma negação dos principais elementos constitutivos do que ele entendia por Movimento Social Urbano. Nesse processo, a obra de Castells foi especialmente elástica e sensível aos debates teóricos e políticos experimentados pela esquerda nas duas décadas mencionadas, influenciada inicialmente pelos debates do marxismo estruturalista de Louis Althusser e Nicos Poulantzas, transitando pela novidade do eurocomunismo até chegar à incorporação na sua definição das concepções sobre movimentos sociais desenvolvidas por Alain Touraine.

Na produção teórica urbana de Manuel Castells, não existe apenas uma definição de Movimentos Sociais Urbanos. Da leitura de suas principais obras podem se depreender três definições distintas: Movimentos Sociais Urbanos como nova forma da luta de classes, MSU como via ao socialismo democrático e MSU como utopias reativas. Não deixa de ser interessante que cada uma delas rivalize e negue a outra. Esse dado deverá ser levado em consideração na hora de compreender como as ciências definiram e se apro- 
ximaram ao Movimento de Pobladores e de Favelados, pois boa parte da produção intelectual sobre esses movimentos desde 1970 em diante se fez aplicando ou contestando a ideia de Movimentos Sociais Urbanos.

\section{Movimentos Sociais Urbanos como nova forma da luta de classes}

Esta fase coincide com o período em que Castells trabalhou no Chile estudando o Movimento de Pobladores e com a publicação de $A$ Questão Urbana, obra na qual este autor desenvolve sua tentativa mais ambiciosa de compreensão do urbano desde uma perspectiva materialista.

A Questão Urbana foi publicado originalmente em francês em 1972, e nele o sociólogo espanhol visava reinterpretar a problemática urbana desde a perspectiva do materialismo dialético, para o qual esperava estudar a produção das formas espaciais a partir da estrutura social de base, ou seja, o modo de produção capitalista e os processos e unidades de reprodução social da força de trabalho. Para tanto, empreendeu uma crítica descarnada contra o que ele considerava como o conjunto de teorias sociológicas idealistas sobre o urbano e a cidade, tanto na sua versão de direita, a Escola de Chicago, quanto na sua versão de esquerda, Henri Lefebvre. N'A Questão Urbana, o urbano, mais que um objeto teórico, é um objeto ideológico; logo, a crítica à sociologia urbana toma a forma de uma crítica à ideologia urbana que está oculta nas práticas das classes dominantes para reproduzir a força de trabalho e as relações sociais de produção.

A ideologia urbana é definida por Castells como aquela visão específica que capta os modos e as formas de organização social, característicos de uma fase da evolução da sociedade ligada às condições técnicas e naturais da existência humana e seu marco de reprodução vital, criando, ao mesmo tempo, a possibilidade e a ilusão de uma "ciência do urbano", teoricamente definida pela es- 
pecificidade do seu objeto. O desenvolvimento dessa ideologia estaria associado à perspectiva culturalista que a desenvolveu, reproduzindo um mito da cultura urbana, ou seja, um sistema específico de relações sociais e atitudes (a cultura urbana) que configura um quadro ecológico dado (a cidade).

Portanto, mesmo reconhecendo a existência de especificidades culturais nos diferentes meios sociais, sua postura urbana será eminentemente anticulturalista. Os diferentes "modos de vida" que podem se encontrar no mundo social são inseparáveis da compreensão da estrutura social que os origina, e não se podem depreender automaticamente de uma correlação entre conteúdos culturais e assentamento espacial, tal como era proposto por alguns dos autores da Escola de Chicago em relação à separação campo/cidade.

Esta postura anticulturalista também é aplicável à sua visão de bairro, ou, melhor dito, à sua crítica à ideologia do bairro, que consistiria em tratar formas de vida social como dados naturais ligados a um marco espacial:

Assim, pois, o debate empirista sobre a existência ou não existência de bairros na sociedade moderna, ou sobre a emergência eventual de novos laços sociais nos conjuntos residenciais suburbanos, simplesmente não tem sentido, formulado nestes termos: não se descobrem 'bairros', como se vê um rio; se lhes constrói, se localizam os processos que levam à estruturação ou à desestruturação dos grupos sociais no seu habitar, ou seja, que se integra a estes processos o papel jogado pelo 'marco espacial', o que vem, portanto, a negar o espaço como 'marco' para o incorporar como elemento de uma determinada prática social. (CASTELLS, 2008, p. 4).

O mesmo é válido para o estudo das "subculturas urbanas", nas quais cada grupo racial ou minoritário produziria um determi- 
nado espaço de acordo com seu tipo de comportamento ou cultura. Para o autor, os meios urbanos só podem ser compreendidos como produtos sociais da estrutura, e a relação entre espaço e sociedade deve ser estudada como problemática e não como eixo explicativo da diversidade da vida social. $\mathrm{Na}$ ideologia urbana produzida pela sociologia, confunde-se num mesmo discurso a problemática das formas espaciais ligada à reprodução da força de trabalho e a especificidade cultural da sociedade moderna.

Seguindo essa lógica, Castells argumentará que não tem teoria do espaço separada de uma teoria social geral, pois não existe teoria do espaço como tal, mas sim um desdobramento e especificação da teoria da estrutura social, a partir da qual se podem explicar as características das formas sociais e espaciais. Usando como suas principais fontes teóricas a Althusser e Poulantzas, Castells (2008, p. 154) empreenderá a tarefa de prolongar os conceitos fundamentais do materialismo histórico ao campo urbano, sob o suposto de que "analisar o espaço enquanto expressão da estrutura social equivale a estudar sua elaboração pelos elementos do sistema econômico, do sistema político e do sistema ideológico, assim como por suas combinações e as práticas sociais que derivam disso”. A pergunta que está por trás deste esforço é: quais são as leis que relacionam espaço e sociedade? Uma primeira tentativa de resposta pode ser encontrada na definição que ensaia de espaço:

O espaço é um produto material em relação com outros elementos materiais, entre eles os homens, os quais contraem determinadas relações sociais, que outorgam ao espaço (e aos outros elementos da combinação) uma forma, uma função, uma significação social. Não é, portanto, apenas uma ocasião de desdobramento da estrutura social, como a expressão concreta de cada conjunto histórico no qual uma sociedade se especifica. Trata-se, portanto, de estabelecer, ao igual que para qualquer outro objeto real, as leis estruturais e conjunturais que regem sua existência e sua mudan- 
ça, assim como sua específica articulação com outros elementos de uma realidade histórica. (CASTELLS, 2008, p. 142).

Dessa maneira, o processo que estrutura o espaço nas sociedades capitalistas é a reprodução da força de trabalho, sendo que as práticas urbanas conotam a articulação deste processo com o conjunto da estrutura social. O sistema urbano corresponde, portanto, à articulação específica das instâncias de uma estrutura social no interior de uma unidade espacial de reprodução da força de trabalho. Mais especificamente:

A cidade é o lugar geográfico onde se instala a superestrutura político-administrativa de uma sociedade que tem chegado a um grau tal de desenvolvimento técnico e social (natural e cultural) que tem sido possível a diferenciação do produto entre reprodução simples e ampla da força de trabalho, e portanto, originando um sistema de repartição que supõe a existência de: 1) um sistema de classes sociais; 2) um sistema político que assegure ao mesmo tempo o funcionamento do conjunto social e a dominação de uma classe; 3) um sistema institucional de investimento, em particular no referente à cultura e à técnica; 4) um sistema de troca com o exterior. (CASTELLS, 2008, p. 19).

Agora, se a estrutura social, tal como é entendida pelo materialismo histórico, não existe sem contradições, ou seja, sem luta de classes, então resulta lógico que a análise da estrutura do espaço exija o estudo da política urbana, a qual para o autor deveria ser o coração da análise sociológica da questão urbana, pois, embora reconheça a existência de leis estruturais tendenciais do fenômeno urbano, este pode ser sempre influenciado e transformado pela prática social. A análise do processo político permitiria compreender a situação concreta e a transformação da questão urbana. A estrutura urbana sofre transformações tanto pelas intervenções do aparato 
público (planejamento urbano) quanto dos movimentos sociais (urbanos), mas essas intervenções estão incluídas na estrutura das contradições que as constituem, logo, a política urbana só pode ser compreendida à luz da luta de classes.

Já que a economia privada é incapaz de satisfazer as necessidades mínimas de habitação e serviços urbanos, a intervenção do Estado, com seus diferentes organismos a nível local e global, se faz necessária permanentemente. A intervenção do Estado na política urbana ou planejamento urbano é uma forma de reorganização do sistema urbano visando à reprodução estrutural do modo de produção, mediante a regulação das contradições não antagônicas, a repressão das contradições antagônicas e a proteção dos interesses da classe social dominante.

Como contrapartida do planejamento, no campo das lutas políticas, estão os Movimentos Sociais Urbanos (MSU), ou seja, as organizações dos agentes sociais que buscam produzir um efeito qualitativamente novo sobre a estrutura social e urbana. As práticas dos MSU podem chegar a modificar a correlação de forças do sistema urbano, entrando em contradição com a dominação social institucionalizada. Na definição de Castells (2008, p. 208):

O Movimento Social Urbano: sistema de práticas que resultam da articulação de uma conjuntura do sistema de agentes urbanos e das outras práticas sociais, na forma tal que seu desenvolvimento tende objetivamente à transformação estrutural do sistema urbano ou a uma modificação substancial da relação de forças na luta de classes, ou seja, em última instância, no poder do Estado.

Os MSUs são um sistema de práticas sociais contraditórias que questionam a ordem estabelecida a partir de contradiçóes específicas da problemática urbana. Ou seja, ativam novas formas de conflito social ligados à organização coletiva do modo de vida, num contexto onde a influência da vida cotidiana sobre a capaci- 
dade produtiva e sobre a vida de trabalho, em geral, é mais decisiva. Tal como Castells (1973b, p. 16) expressava num texto contemporâneo a $A$ Questão Urbana:

Deparamo-nos assim com a exigência social histórica definida por uma série de direitos à vida (habitação, equipamento, saúde, cultura, etc.) arrancados à burguesia e aos aparelhos do Estado e sobre os quais o tratamento social se torna de mais em mais coletivo e interdependente. Eis o que está na base de uma contradição fundamental, já que este conjunto de 'necessidades coletivas' aumenta paulatinamente com a evolução social (também por causas econômicas e pela luta de classes), apesar de que é, em geral, um setor não rentável para investimento capitalista estendido ao consumo, alveja o consumo individual onde a demanda solvente antecipada é muito mais manipulável. $O$ consumo coletivo (habitação, equipamentos, transportes, etc.) viram assim ao mesmo tempo elementos funcionais indispensáveis, objetos permanentes de reivindicação e setor deficitário na economia capitalista.

Os MSUs se apresentam como as verdadeiras fontes de mudança e inovação da cidade, na medida em que representam um desafio à antiga ordem urbana. Além do mais, eles oferecem a possibilidade de ampliar as alianças do movimento operário, aumentando as forças necessárias para gerar transformações profundas na sociedade. A questão dos MSUs implica, por um lado, a análise dos processos sociais de mudança dos modos de consumo coletivo expressadas na organização urbana e, por outro, a articulação entre novas contradições econômicas e políticas próprias da estrutura social. Cada luta urbana deve ser compreendida no seu conteúdo estrutural.

O que está em jogo com os MSUs é a articulação entre lutas urbanas e lutas políticas, no sentido de que uma determinada reivindicação urbana possa se especificar no campo da luta política, 
criando relações novas entre as classes e se articulando com outros planos das relações sociais. Assim, estamos frente a um movimento social urbano quando existe correspondência entre as contradições estruturais fundamentais do sistema urbano e uma linha “justa” de uma organização que é capaz de relacionar essas contradições com outras que põem em questão a dominação.

Uma simples acumulação de reivindicações urbanas, se se expressa sem objetivos de luta propriamente políticos, se transforma num "tradeunionismo do consumo", uma forma de economicismo de corte quase gremialista que não questiona nem o modo de produção nem sua concreção urbana. A articulação entre reivindicação urbana e luta política não opera por si própria; necessita de um elemento externo, uma intervenção organizada que permita a ligação entre a prática política das massas e a luta política propriamente dita.

É precisamente essa articulação e essa intervenção que Castells observou no Movimento de Pobladores chileno. Nesse caso, a própria definição de pobladores fazia mais referência à questão política que espacial, pois o assentamento espacial do movimento tomava diversas formas: callampas, campamentos, poblaciones etc., sendo que a condição de poblador remetia ao pertencimento a um determinado movimento social.

A aparição do Movimento de Pobladores implicou a incorporação às forças revolucionárias de um contingente significativo de população, caracterizada pela aplicação de uma estratégia de habitação "selvagem" dada por tomadas de terrenos ilegais e cujas reivindicações eram de caráter urbano. Os pobladores se transformaram num eixo fundamental das lutas sociais, assumindo, em determinadas situações, maior importância política que o próprio Movimento Operário. Com sua prática política nos campamentos, segundo Castells, esse movimento inaugurou novas formas de luta e mesmo prefigurou transformações futuras das relações sociais prometidas pelas mudanças que experimentava a sociedade chilena. 
Embora Castells tenha estudado outros exemplos de reivindicação urbana na França, em Quebec e nos Estados Unidos, nesse período, nenhuma das outras experiências satisfazia as exigências de articulação entre a luta urbana e a luta política como o caso dos pobladores chilenos. Estes demonstraram que a mobilização em torno a uma contradição secundária de consumo pode chegar a se transformar numa contradição principal em determinados momentos da luta social.

Nossas análises mostram a extrema dependência das lutas urbanas em relação às outras lutas sociais, e até sua incapacidade de desenvolvimento real sem uma articulação com os conflitos políticos que permanecem essencialmente dominados pelas formas atuais de enfrentamento entre Capital e Trabalho. Mas isto não significa dizer que as lutas urbanas sejam necessariamente relegadas ao mundo do reformismo gestionário. Pelo contrário, conseguimos constatar sua importância decisiva em certas conjunturas políticas, já que uma contradição estruturalmente secundária pode ser conjunturalmente principal. Isto signigica que não se poderá julgar a importância política de um movimento urbano sem considerar os efeitos que produzem sobre as relações de poder entre as classes sociais numa situação concreta (CASTELLS, 1973b, pp. 128-9).

\section{Movimentos Sociais Urbanos como via democrática ao socialismo}

Um dos aspectos mais interessantes da obra urbana de Manuel Castells é a ampla variedade de experiências empíricas de movimentos reivindicatórios urbanos estudados. Nesta fase do autor, o caso analisado é o Movimento Citadino de Madri, articulado mais ou menos desde $1974 \mathrm{em}$ plena ditadura franquista, num texto chamado sugestivamente de Cidade, Democracia e Socialis- 
mo (CASTELLS, 1980), publicado originalmente em 1977 na Espanha.

Depois do amargo e trágico final do Movimento de Pobladores chileno, agora o autor parece empolgado novamente com a revitalização das lutas urbanas como forma de politização dos setores populares, mas desta vez de uma forma completamente diferente da experiência andina.

Um novo espectro ronda o mundo em crise do capitalismo avançado. Associações de vizinhos, comitês de bairro, organizações de usuários de serviços públicos, associações de pais de alunos, sindicatos de consumidores, organismos de participação, clubes culturais, centros sociais, toda uma infinidade de expressóes citadinas que lutam, organizam-se e tomam consciência, na tentativa de transformar a base material e a forma social da vida cotidiana (CASTELLS, 1980, p. 19).

Mantendo a ideia da existência de três níveis fundamentais dos MSUs, a saber, a relação diferencial com as contradições da cidade, sua inserção na estrutura de classes sociais e sua articulação com a dinâmica política geral da sociedade, o autor tentará mostrar como a evolução do movimento citadino madrilenho esteve estreitamente ligada ao processo político de luta pela democracia, transformando-se num dos principais componentes que permitiram o retorno democrático.

Para ele, isto não era um fenômeno isolado, pois observava a aparição de movimentos similares ao citadino em quase todas as sociedades capitalistas avançadas, virando um dos elementos característicos dessa etapa da dinâmica social. Porém, o caso espanhol apresentava um mérito distintivo: o fato de se desenvolver no meio de uma ditadura de traços fascistoides.

Efetivamente organizado em base a reivindicações "secundárias” - moradia, transporte, segurança na circulação, sanitárias, 
de ensino, de preservação de espaços verdes, de instalações esportivas e de carestia da vida -, o Movimento Citadino madrilenho proporcionou aos vizinhos que o compunham a possibilidade de participar livremente na resolução de seus problemas mais imediatos, apesar dos momentos de intensa repressão franquista. Eles conseguiam na prática o que o franquismo negava oficialmente, mostrando "seu caráter objetivamente democrático, que os transformou em escola de democracia e fator decisivo na luta pela liberdade" (CASTELLS, 1980, p. 81).

Mas o que origina os Movimentos Sociais Urbanos como o Movimento Citadino madrilenho? A resposta de Castells a esta questão está em continuidade com sua obra anterior: a crise urbana provocada pelo capitalismo e a resposta popular. Por um lado, o capitalismo monopolista possuiria uma tendência à crise, expressada agora como crise urbana cada vez mais profunda; por outro, as classes sociais lutam por defender seus interesses frente ao capital e frente ao Estado (repressivo ou negociador de interesses). A crise urbana se produz pela crescente incapacidade do capital de assegurar a produção, distribuição e gestão dos meios de consumo coletivo necessários à vida cotidiana, desde a moradia até as escolas, passando pelos transportes, saúde, áreas verdes etc., transformando a crise em algo mais que uma simples deficiência do sistema. A crise se apresenta como uma consequência da lógica do desenvolvimento capitalista. A concentração do capital gera sucessivas concentraçóes: econômica, social e espacial dos meios de produção e das unidades de gestão, assim como da força de trabalho nas cidades, provocando uma maior interdependência dos meios de consumo. $\mathrm{O}$ fenômeno anterior transforma o consumo numa dimensão cada vez mais importante; por sua vez, as massas populares começam a ser mais exigentes com a satisfação de suas necessidades. Dessa maneira, 
Aquilo que é exigido pelo sistema em conjunto, mal pode ser atendido por algum capital privado. E é essa a contradição estrutural que provoca a crise urbana: os serviços coletivos requeridos pelo modo de vida suscitado pelo desenvolvimento capitalista não são suficientemente rentáveis para ser produzidos pelo capital, com vistas à obtenção do lucro. Daí nasce a crise urbana como crise de serviços coletivos necessários à vida das cidades. Da impossibilidade do sistema em produzir aqueles serviços cuja necessidade ele suscitou. (CASTELLS, 1980, p. 23).

Essa incapacidade provoca a necessidade da presença do Estado, politizando de fato a questão do consumo.

Mas a intervenção do Estado não constitui um suposto mecanismo regulador neutro aplicado a um sistema em desequilíbrio. É a resultante de um processo político, amplamente determinado pelas lutas de classe. Nesse sentido, os conflitos políticos serão fatores essenciais na gestão dos meios coletivos de consumo e do sistema urbano por eles determinado [...] o Estado se transforma no patrão dos serviços públicos estruturados da vida cotidiana. $\mathrm{E}$ a partir daí, as contradições que se desenvolvem na esfera do consumo coletivo, os conflitos que nascem da organização urbana, tendem a se relacionar, mais ou menos diretamente, com a gestão do Estado e com as orientações políticas subjacentes. De fato, pois, a intervenção do Estado no setor urbano, em vez de superar a crise habitacional e de equipamentos criada pela contradição inerente à urbanização capitalista, politiza e globaliza os conflitos urbanos, ao articular diretamente as condições materiais de organização da vida cotidiana e do conteúdo de classe das políticas do Estado. (CASTELLS, 1980, p. 24).

Madri experimentava essa crise urbana como uma especificação das contradições gerais do desenvolvimento urbano capi- 
talista, mas com a particularidade outorgada pelas contradições políticas próprias de uma ditadura como a franquista. Sem dúvida, o fato de ter se desenvolvido no meio de uma ditadura dava um mérito adicional ao Movimento Citadino, mais ainda conseguindo mobilizar e organizar de maneira estável os moradores que o compunham, impondo na prática o direito de associação e de reunião proibidos pela ditadura. $\mathrm{O}$ movimento permitiu a defesa das condições de vida da população no contexto da crise urbana, promovendo formas de relações sociais mais solidárias e humanas frente às propostas pelo capitalismo e o franquismo. Ao mesmo tempo, complementou a luta do movimento operário, o qual, para Castells, continuava sendo o verdadeiro motor da luta contra a ditadura, ampliando a base social de apoio do movimento democrático. Sendo que também permitiu a reconstrução de uma trama social e de vida associativa nos bairros que tinham sido exterminados pelo terror político.

No estritamente urbano, o Movimento Citadino foi capaz de modificar profundamente as condições de desenvolvimento urbano nas zonas onde se mobilizou, forçou decisões urbanísticas, permitiu o controle dos moradores de planos, modificou a distribuição de equipamentos, assim como alguns planos de remodelação, tudo em um marco de urbanização autoritária que teoricamente outorgava carta branca às autoridades do regime para desenvolver seu modelo de cidade.

Porém, a principal potencialidade identificada por Castells no Movimento Citadino madrilenho era sua possível contribuição para uma via democrática ao socialismo. Surpreendentemente para quem, no Chile, se posicionou mais próximo da esquerda radical que da esquerda democrática, no caso espanhol, o autor defenderá as concepções levantadas na época pelo eurocomunismo, sendo sua principal referência política no texto Santiago Carrillo, Secretário Geral do Partido Comunista Espanhol e um dos ideólogos do eurocomunismo. Caso se considere a via chilena ao 
socialismo como uma das fontes inspiradoras do eurocomunismo (SANTONI, 2010), então se poderia dizer que Castells sofreu de um allendismo tardio na sua compreensão do socialismo e do papel dos movimentos sociais nele. A via democrática ao socialismo se faz com as massas, pelas massas e para as massas; logo, o que a viabiliza é a conscientização da grande maioria dos trabalhadores manuais e não manuais. Eis a importância dos MSUs, pois estes oferecem a oportunidade de que, mediante a prática coletiva de luta e organização, um número maior de cidadãos compreenda seus interesses e as contradições da dominação capitalista. $\mathrm{O}$ caráter interclassista dos MSUs permitiria uma ampliação da base social das lutas anticapitalistas, outorgando às lutas urbanas a condição de componente essencial da via democrática ao socialismo, pois as práticas do movimento que constrói uma cidade mais democrática fazem parte do espírito desse tipo de socialismo. Nas palavras do autor:

Isto é, de um caminho que trata, por um lado, de desenvolver cotidianamente a luta e a organização das massas populares em defesa de seus interesses e como expressão de suas próprias tendências sociais e culturais; por outro lado, de acrescentar a força política da alternativa socialista e de assegurar sua presença nas instituições representativas do Estado em todos os níveis; enfim, de mudar qualitativamente a política e a estrutura desse Estado, articulando-o cada vez mais estreitamente às organizações populares e apoiando-se na força autônoma dessas organizações para modificar a correlação de forças sociais e defender as conquistas que se vão alcançando no seio do Estado e na relação entre o Estado e a sociedade (CASTELLS, 1980, p. 168).

Castells (1980, p. 167) parece mais preocupado com a construção de uma hegemonia popular em termos gramscianos, do que com um assalto ao Palácio de Inverno, o que fica em evidência no 
fato de renegar o MSU como um mecanismo de construção de poder popular:

O perigo das iniciativas necessárias para avançar na direção assinalada de extensão da democracia, é que o movimento citadino seja instrumentalizado em favor de uma estratégia política radicalmente diversa da descrita, que, para simplificar, chamaremos de duplo poder ou de poder popular. Tratar-se-ia, nesse caso, de opor o movimento citadino às instituições democráticas, a democracia direta à democracia representativa, ou, como diriam seus partidários, a 'democracia popular' à 'democracia burguesa'. Tal posição demonstra uma profunda incompreensão do que seja o Estado democrático e das razões históricas do desenvolvimento da democracia representativa, produto da luta de classes e conquista popular contra a burguesia.

Talvez seja esse traço de negação do "poder popular" o elemento que mais distancia de um primeiro Castells, que identificava na experiência poblacional do Movimento de Esquerda Revolucionária chilena e seus campamentos revolucionários a expressão mais avançada dos MSUs. Porém, o autor ainda reivindicará o papel distintivo dos partidos políticos na construção dos MSUs, principalmente a partir da análise do trabalho de massas do Partido Comunista Espanhol na consolidação e desenvolvimento do Movimento Citadino. A politização que caracteriza um MSU torna quase inevitável a intervenção de um agente externo, porém isso o confronta com a ameaça permanente de perda da autonomia e do raio de alcance de sua própria política.

A subordinação orgânica e política de muitas associações às organizações dos partidos foi uma consequência quase necessária da politização imediata do movimento citadino, pelas condições de repressão em que se desenvolveu, principalmente em Madri, 
assim como pela urgência das tarefas políticas na luta contra a ditadura. Mas o fato de que a utilização política direta das associações de vizinhos fosse explicável e difícil de evitar não diminuiu as consequências produzidas no movimento citadino, no sentido de acentuar seu caráter vanguardista e de frear consideravelmente sua representatividade social. (CASTELLS, 1980, p. 150)

A própria existência do Movimento Citadino representava um desafio à ditadura franquista, e uma das suas primeiras lutas foi por sua própria existência legal. Assim, mesmo tendo uma origem claramente reivindicativa, sua luta nasce politizada e logo fica associada à exigência de liberdades democráticas. $\mathrm{O}$ movimento foi reprimido, perseguido e em mais de uma ocasiáo teve que se enfrentar com a polícia. Portanto, a conclusão de que era necessário um Estado democrático para o desenvolvimento pleno do movimento associativo se espalhou facilmente entre os membros do movimento. A preocupação do autor com o "tradeunionismo" urbano como um desvio dos MSUs já não está presente, porque a reivindicação urbana num contexto autoritário é inseparável da questão política:

Nesse sentido, o movimento citadino não é mais nem menos reformista que o movimento operário, em princípio e em termos estruturais. Porque tudo depende da maneira como for articulada a luta política [...] O fator determinante não é a fábrica ou o bairro, são as relações políticas entre as classes, em particular aquelas vinculadas ao processo de ocupação-transformação do Estado. E, desde esse ponto de vista, os movimentos urbanos desempenham hoje, na Europa ocidental, um papel decisivo na construção de um novo bloco histórico das classes populares, que torne possível o desenvolvimento da via democrática para o socialismo. (CASTELLS, 1980, p. 33) 
Da mesma maneira, a anterior postura anticulturalista do autor desaparecerá nesta fase. Observar-se-á assim uma valorização do feminismo como forma de transformação radical das relações sociais que começa desde uma base residencial. Assim como também superará sua visão negativa da crítica ecologista, compreendida n'A Questão Urbana como uma forma de "scoutismo", agora entendida como uma experiência cotidiana que oferece a possibilidade do questionamento da lógica capitalista dominante.

No cotidiano do Movimento Citadino, o valor de uso começa a substituir o valor de troca como norma básica e a cidade começa a ser reivindicada como um modo de vida. E essa "descapitalização da sociedade capitalista a nível cultural pode ser potencialmente um instrumento de subversão e de transformação se for levada a cabo a necessária mediação política considerando a correlação de forças e a estratégia adequada no âmbito do estado" (CASTELLS, 1980, p. 37).

Nesse sentido, a diversidade do Movimento Citadino não é um sinal de fraqueza, mas sim de ampliação de sua esfera de influência como forma de interclassismo que possui uma comum oposição à lógica de um desenvolvimento urbano orientado pelo capital; embora o interclassismo não implique uma pulverização da classe, considerando a existência da segregação urbana, a qual provoca a existência de zonas mais homogêneas dentro da cidade, cuja luta fica marcada diferencialmente pelo setor social majoritário que a caracteriza.

Outra dimensão que aparece reabilitada em relação a sua obra anterior é a do bairro. Castells (1980, p. 80) identificará como fundamental a relação entre a luta reivindicatória e a vida social do bairro para a consolidação do Movimento Citadino.

Lá onde existe uma forte solidariedade entre os vizinhos, o movimento reivindicatório pôde-se desenvolver e organizar rapidamente, sendo particularmente significativo, nesse aspecto, o mo- 
vimento dos favelados, ao mesmo tempo comunidade de base, instrumento de luta e órgão de participação política. É interessante que a relação também funcione em sentido inverso: o desenvolvimento da luta, a criação de associações de reivindicação, cria laços sociais onde antes imperava o individualismo; tende a substituir o anonimato e a impessoalidade por uma trama social e uma série de atividades que modificam, pouco a pouco, a vida cotidiana das pessoas. É assim que a luta por um novo tipo de cidade torna-se cada vez mais inseparável da luta por um novo tipo de vida social.

O Movimento Citadino, por um lado, permite o surgimento de novos valores sociais e de novas formas urbanas e, por outro, se torna decisivo na luta pela democracia, impondo a liberdade de associação na prática, legitimando o protesto e a organização dos moradores dos bairros. Em certa medida, antecipava a forma de democracia exigida nas ruas, pois a aplicava na sua própria organização e na gestão do espaço urbano.

\section{Movimentos Sociais Urbanos como utopias reativas}

A publicação de La Ciudad y Las Masas (CASTELLS, 1986), cuja primeira edição foi publicada em inglês em 1983, representa um dos projetos teóricos mais ambiciosos de Manuel Castells, comparável em certa medida com $A$ Questão Social, mas sem o mesmo impacto e com mudanças significativas em relação às teses propostas na primeira fase do pensamento urbano do sociólogo espanhol. Em La Ciudad y Las Masas, Castells visa a construção de uma teoria da mudança social urbana onde o núcleo central são os MSUs, mantendo sua preocupação sobre a análise da estrutura, mas integrada aos processos de crise e mudança que o modificam. Ao mesmo tempo, manterá bastante continuidade com a fase dos MSUs como via para o socialismo democrático, porém com uma 
visão muito mais restrita do alcance destes tipos de movimentos, que serão entendidos como projetos utópicos de caráter reativo, mas que conservam um potencial transformador.

Longe do marxismo estruturalista que originalmente o inspirou, neste texto, o autor ampliará largamente o leque de autores com os quais dialoga: Tilly, Melucci e Touraine, sendo especialmente este último autor o que mais marcas deixou na nova compreensão que Castells vai propor no texto. Particularmente em relação a Poulantzas, marcará distância do seu conceito de formação social, de que toda sociedade é uma combinação de diferentes modos de produção sob o domínio de um deles, mostrando preferência pela ideia de processo histórico:

Porém, seria errado analisar o problema apenas sob este enfoque [de formações sociais], pois uma vez que uma sociedade dada está estruturada, se admitimos que a combinação que subjaz à sua estrutura é única, também o serão sua evolução, sua dinâmica, suas lutas, sua mudança. Logo, não estamos frente a formações sociais, mas frente a processos históricos. (CASTELLS, 1986, p. 416).

Sua tentativa será não a construção de uma teoria transistórica da sociedade e sua especificação da questão urbana, mas sim uma história teorizada dos fenômenos sociais. Para tanto, mobilizará uma quantidade impressionante de casos de MSU de diferentes partes do mundo.

Conservando a ideia original da crescente importância do consumo coletivo através dos serviços urbanos e da incapacidade do capital privado de responder a essas exigências, e obrigando a intervenção sistemática do Estado nos problemas urbanos, que dá a eles uma centralidade nos conflitos políticos contemporâneos, são algumas de suas proposições básicas: 
- A cidade é um produto social resultante de interesses e valores sociais em disputa.

- As principais inovações da cidade geralmente se originam pela mobilização e exigências das massas populares; quando estas conseguem modificar a estrutura urbana, estamos ante a presença de MSU.

- Porém, a estrutura urbana também é criada pela ação dos interesses dominantes e deve ser considerada para sua compreensão.

- Portanto, a ação dos MSU não é única causa da mudança social urbana; existem outras como a função autônoma do Estado, a relação entre sexos, os movimentos étnicos e nacionais e os movimentos citadinos.

A valorização, neste último ponto, do papel das relações de sexo ou dos grupos étnicos na produção do espaço já permite identificar a influência de Alain Touraine nesta nova fase teórica de Castells. O significado do urbano pode mudar pela primazia da experiência urbana como valor de uso, como é proposto por alguns dos Novos Movimentos Sociais, em contraposição ao valor de troca priorizado pelo capitalismo.

Os MSUs seriam, mais especificamente, ações coletivas conscientemente destinadas a transformar interesses e valores incorporados nas formas e funções de uma cidade dada, sendo sua proposta uma nova relação entre espaço e cidade. As fontes dos MSUs seriam movimentos de protesto urbano, mobilizados: por demandas de consumo coletivos, pela defesa de uma identidade cultural associada a um território específico ou por demandas políticas em relação ao governo local. Nessa constelação, os MSUs seriam agentes da mudança social, mas com restrições:

Nossa principal proposição é que existe uma conexão íntima entre os temas, objetivos e experiências dos movimentos sociais ur- 
banos, e o processo global do conflito histórico e a mudança em nossas sociedades. Não é que os movimentos urbanos sejam os novos atores históricos que criam a mudança social, nem a fonte essencial das formas sociais alternativas. $\mathrm{O}$ que afirmamos, mais bem, é que os movimentos urbanos não são expressões aleatórias de descontento que variam de uma cidade a outra, mas que na sua estrutura e seus objetivos, portam os estigmas e projetos de todos os grandes conflitos históricos de nosso tempo. (CASTELLS, 1986, p. 429).

Os MSUs já não aparecem com uma nova forma de luta de classes ou de qualquer outro tipo (gênero ou étnica). Possuem uma base não classista, são socialmente diversos. São atores urbanos definidos por seus objetivos e por sua condição urbana, e podem aspirar a: (1) conseguir organizar os residentes de uma cidade em função de seu valor de uso, em contraposição à mercantilização da experiência urbana (como valor de troca), o que Castells denomina "sindicalismo de consumo coletivo"; (2) a busca da identidade cultural ou a defesa de uma cultura local autônoma, o que o autor chama de "comunidade"; (3) enfim, o movimento "citadino" que luta pela conquista do governo local, descentralização dos bairros e autogestão urbana. Os MSU são portadores de um conceito alternativo de cidade. De modo resumido:

Assim, a experiência observada dos movimentos urbanos aponta para um significado urbano que representa a alternativa à cidade que surge dos interesses e valores da classe dominante. A cidade alternativa é, portanto, uma rede de comunidades culturais definida pelo tempo e o espaço, autogestionada politicamente olhando à maximização do valor de uso para seus residentes. Este novo signigicado urbano não é nem a imagem ideal nem o sonho de uma noite de verão: é o conjunto de objetivos que nasce da prática dos movimentos urbanos que temos observado, e seu significado 
e existência não são contraditos pela quantidade de dados secundários conhecidos sobre outros movimentos urbanos de outras cidades e outras sociedades [...] Os movimentos são projetos de cidade, vida social, e funções e formas urbanas (predeterminadas pelo significado urbano) que surgem da capacidade dos pobladores urbanos para produzir e controlar seu entorno, seu espaço e seus serviços urbanos (CASTELLS, 1986, p. 432).

Os MSUs são uma reação à "cidade selvagem" como expressão espacial de uma estrutura não reconhecida que produz exploração, alienação e opressão. A expressão material e espacial das formas de urbanização selvagem experimentada pela sociedade provocam reações que contêm o germe da mudança social. Porém, os MSUs não são agentes da mudança social estrutural, mas se expressam como sintomas de resistência à dominação social mesmo nesse processo, chegando a ter efeitos importantes nas cidades e, por extensão, nas sociedades. Apesar da proposta de cidade alternativa implícita na existência dos MSUs, esta é uma utopia restrita sem capacidade de modificação real da estrutura social. Esses movimentos estariam condenados a cumprir um papel reativo e defensivo pela sua incapacidade de promover um projeto histórico viável de produção econômica e social. A estrutura social está fora do alcance das comunidades locais, e as explosões urbanas carecem de instrumentos e capacidade para propor uma reorganização da produção, do consumo e da circulação. Segundo a explicação de Castells (1986, p. 439):

Como todas estas fontes potenciais de conflitos em nossa sociedade não têm meios autônomos de expressão, organização e mobilização, têm se unido de uma maneira negativa e reativa na forma de movimentos urbanos. Quando são reações unidimensionais primitivas, ganham a forma de protesto urbano. Quando têm desenvolvido uma visão global alternativa, formam uma con- 
tracultura, e se sentem mais cômodas se definem sua alternativa num território: propõem uma organização social alternativa, um espaço alternativo, uma cidade alternativa. Viram um movimento social urbano. Mas esse movimento não pode ser 'proativo', apenas 'reativo', exceto na sua dimensão utópica. Mas não podem ser um movimento social, apenas o sintoma de um limite social, pois a cidade que projeta não está nem pode estar conectada a um modo alternativo de produção e desenvolvimento, nem a um Estado democrático adaptado aos processos mundiais de poder. Os movimentos sociais urbanos estão, pois, orientados a transformar o significado da cidade sem poder transformar a sociedade. Eles são uma reação, não uma alternativa: reclamam uma profundidade de existência, sem ser capazes de criar uma nova cultura. Projetam o perfil do mundo que desejam, sem saber por que, nem como, nem se é possível. Quando as instituições permanecem isoladas ou insensíveis, os bancos mantêm seus altos tipos de juros, a polícia volta a ocupar as ruas, o espaço significativo continua se desintegrando, e os movimentos sociais urbanos não propõem já uma cidade alternativa. Em vez disso, seus elementos fragmentados empreendem a destruição da cidade que os rejeita. Observamos e analisamos sua esperança de uma nova sociedade, tal e como se projetava no espaço que desejavam e na cidade que queriam. Mas se tais apelos não são ouvidos, se as vias políticas permanecem fechadas, se os novos movimentos centrais (feminismo, novo movimento operário, autogestão, comunicação alternativa) não frutificam plenamente, então, os movimentos urbanos - utopias reativas que tentaram iluminar o caminho que não podiam percorrer - voltarão, mas desta vez como fantasmas urbanos, dispostos a incendiar as muralhas hostis de sua cidade cativa.

Embora o marxismo estruturalista já não seja a principal fonte teórica neste texto, a força da estrutura, o peso do modo de 
produção aparece como uma instância inatingível pela agência dos MSUs ou de qualquer outro movimento. $\mathrm{O}$ voluntarismo otimista das fases anteriores dos MSUs desaparece neste ponto; nem o Movimento de Pobladores chilenos fez a revolução, nem o Movimento Citadino madrilenho abriu o caminho para um socialismo democrático. Sem dúvida, Castells apostou muito nos MSUs, que considerou como exemplares, e seu estudo durante seu processo de desenvolvimento, sem conhecer seu desenlace, o levou a exagerar o potencial transformador de suas práticas. Em La Ciudad y Las Masas, o processo é inverso, amplia sua definição, permitindo a classificação de um maior número de experiências como MSU, mas limita o alcance e o potencial deles. Por isso, resulta sumamente ilustrativa a avaliação que o autor faz no texto do próprio Movimento de Pobladores chilenos para mensurar o grau de mudança experimentado na concepção de MSU proposta por Castells nesta etapa.

No extenso capítulo que Manuel Castells dedica à América Latina em La Ciudad y las Masas, os MSUs aparecem como subordinados ao que ele chama de populismo urbano. As diferentes tentativas de superação da condição de dependência dos países latino-americanos tiveram como consequência a criação de uma nova relação entre o Estado e as massas populares, caracterizada pela subordinação das últimas sob a forma do populismo urbano.

Por populismo urbano entendemos o proceso de estabelecimento da legitimidade política baseado numa mobilização popular sustentada pela provisão de terras, habitação e serviços públicos, e encaminhada, por sua vez, a obter-los. Este é um mecanismo muito tradicional que existe em numerosos países desde longo tempo, mas sua importância quantitativa e seu significado qualitativo têm-se visto intensificados nos últimos anos pelo ritmo 
e as formas de urbanização nas sociedades dependentes. (CASTELLS, 1986, pp. 245-6)

Incorporando a literatura em voga na época sobre populismo na América Latina, o autor definirá a existência de uma dialética entre a integração social e a mudança na relação entre Estado e pobladores. Embora salientando a condição de subordinação das massas populares às diferentes formas de clientelismo urbano, reconhecerá, nesta nova relação, a possibilidade de desencadeamento de MSUs autônomos. Sem cair na ideia de "massa de manobra" da literatura sobre populismo, principalmente graças à incorporação das noções de Anthony Leeds sobre este tema, Castells mostrará como algumas das tentativas de controle dos pobladores na América Latina tiveram o efeito contrário de ativar movimentos com força e agenda própria. Nos termos do autor:

A substituição de uma relação de patronaz go clássica - entre classe governante e setores populares - por uma mobilização populista controlada, amplia a hegemonia da classe governante sobre esses setores, que são organizados sob a etiqueta de 'marginais urbanos. Mas a crise de tal hegemonia, se se produz, tem consequências muito mais graves para a ordem social existente que a ruptura dos vínculos de patronazgo tradicionais de uma maquinaria política (CASTELLS, 1986, p. 273).

$\mathrm{Na}$ América Latina, a urbanização acelerada e a nova divisão internacional do trabalho [...] propiciaram o surgimento de um populismo urbano no qual os pobladores ofereceram sua adesão política e sua heteronomia cultural em troca de serviços urbanos e do direito de se instalar nas margens do sistema econômico mundial. Os movimentos seguiram uma pauta contraditória de reivindicação, negociação, mobilização e integração, ligada ao 
destino dos atores políticos em que sempre se apoiaram os ocupantes ilegais (CASTELLS, 1986, p. 438).

Precisamente um caso de movimento autônomo é o dos pobladores de Santiago do Chile, experiência da qual o autor fará uma avaliação extremamente crítica. Para começar, a presença de partidos políticos, que anteriormente foi celebrada pelo autor por politizar o movimento e por lhe outorgar uma centralidade conjuntural pela coincidência táctica de estratégias políticas diferentes, agora é compreendida como um dado negativo.

Cada campamento dependia da linha política do dirigente fundador, o que tornava os bairros politicamente homogêneos, sem pluralismo. Da mesma maneira, a participação no processo político de cada campamento dependia da linha política dominante, logo não teria existido um "movimento de pobladores", mas ramas de pobladores de cada partido em disputa. Embora os pobladores tenham sido bem sucedidos na transformação do sistema urbano, a possibilidade de geração de novas práticas locais, de fato, estava limitada pelas instituições políticas ainda dominantes. Os partidos políticos, na verdade, utilizaram os pobladores em função dos seus interesses particulares, reduzindo o nível de participação das bases sociais. Castells (1986, p. 433) manterá a ideia de necessidade da politização, mas descartará o papel dos partidos políticos nesse processo:

Uma condição sine qua non: embora os movimentos sociais urbanos tenham que estar conectados com o sistema político para alcançar, ao menos em parte, seus objetivos, devem ser autônomos, desde o ponto de vista de sua organização e de sua ideologia, em relação a qualquer partido. A razão é que a transformação social e a luta política, a negociação e a gestão, embora estejam intimamente relacionadas e sejam estreitamente interdependentes, não operam no mesmo plano da estrutura social. 
Os MSUs na América Latina, mesmo no caso chileno, aparecem subordinados ao sistema político. Este seria o custo da conquista de serviços urbanos e da oportunidade de construir comunidades culturais de caráter popular. A própria vulnerabilidade dos ocupantes ilegais das tomadas de terreno os fazia dependentes do sistema político: sem apoio político, sem a tolerância do Estado, a presença física dos pobres urbanos na cidade estava em questão. Embora os MSUs tenham conseguido mudar as formas urbanas, ficaram dependentes da sorte das suas lideranças políticas, tal como teria acontecido no Chile: quando os partidos que animaram e dirigiram o movimento foram derrotados, o movimento de pobladores desapareceu junto com eles.

Este teria sido o caso até de Nueva La Habana, o campamento modelo da esquerda radical e outrora a corporização histórica dos MSUs como nova forma da luta de classes. Baseando-se no excelente trabalho de Christine Castelain (1975) sobre este bairro, no qual detectou uma significativa brecha ideológica entre a vanguarda política de militantes do MIR e os pobladores, gerando uma contínua tensão dentro do campamento nos seus três anos de existência, Manuel Castells revisitará boa parte de suas ideias sobre esse tópico.

O elevado nível de politização e consciência não era atributo do campamento, mas apenas das lideranças ligadas ao MIR e, embora fosse possível apreciar uma consciência coletiva e simpatia com a política de esquerda, parte importante dos pobladores cultivava uma atitude individualista e utilitarista em relação à política habitacional do Movimento de Pobladores.

Nueva La Habana não se negou a contribuir à parte que lhe correspondia na mobilização nem cultivou uma atitude hipócrita em relação aos ideais socialistas em troca do patronazgo urbano. Porém, o que estava claro para todos os observadores era que essa luta era um meio, e não um fim, para imensa maioria dos pobla- 
dores, que Nueva La Habana era uma comunidade introspectiva que sonhava com uma barriada pacífica, tranquila e bem equipada, enquanto os dirigentes do MIR, conscientes da agudização do conflito político, desejavam elevar o nível de militância de maneira que todo o acampamento virasse uma força revolucionária. Seus esforços desdobrados nessa direção resultaram inúteis (CASTELLS, 1986, p. 285).

Se os pobladores instrumentalizaram a política do MIR para conseguir habitação, por sua vez o MIR utilizou a massa de pobladores em função de sua política nacional na conjuntura específica da polarização prévia ao golpe militar. Houve uma utilização recíproca, mas com significativas consequências para a organização urbana da cidade de Santiago do Chile.

A mobilização geral de outubro de 1972 contra a ofensiva conservadora no Chile deu um novo papel ao acampamento; primeiro, na batalha pela distribuição, e mais tarde, no apoio à construção de cordões industriais (comitês industriais) e comandos comunais (sindicatos urbanos) como centros de poder popular revolucionário. Num gesto favorável a esta estratégia, os militantes de Nueva La Habana tentaram ocupar, em 3 de abril de 1973, o Organismo Nacional de Distribuição Comercial (CENADI), levantando barricadas na principal avenida de Santiago, Vicuña Maskena, e fazendo frente furiosamente à polícia durante todo um dia. Por causa disso, Nueva La Habana manteve sua função subordinada de ramo de um partido político, adotando diversas táticas, segundo as diferentes orientações tomadas pela atividade política do MIR. E assim, se o 'campamento modelo' foi uma expressão da capacidade militante dos ocupantes ilegais para construir sua cidade e ensaiar novos modos de vida comunais, foi também, acima de tudo, uma arma de organização de um partido. (CASTELLS, 1986, p. 289) 
Todavia, o autor não negará a condição de MSU do Movimento de Pobladores, pela mobilização de massas populares em função de questões urbanas e pela contribuição política ao impulso da mudança social. Efetivamente, com o Movimento de Pobladores, os setores urbanos populares, antes passivos, foram protagonistas da cena política nacional. Até poderia ter sido potencialmente decisivo na transformação revolucionária da sociedade, mas não conseguiu projetar uma aliança estável e hegemônica com o movimento operário e com outras capas sociais subalternas. Embora os partidos políticos de esquerda no Chile tenham compreendido essa potencialidade, combatendo as tendências populistas no seu seio, ao mesmo tempo, sobrepolitizaram-no, socavando a unidade do movimento e a definição autônoma dos seus objetivos. O Movimento de Pobladores virou um amplificador das divisões ideológicas da esquerda chilena. Assim, no momento de maior fragmentação da esquerda prévio ao golpe de Estado, cada campamento se alinhou com a tendência correspondente à sua força hegemônica e o movimento deixou de ser uma entidade identificável: "a desaparição do movimento de pobladores em 1972-73 foi a consequência da lógica da disciplina de partido, que veio a substituir as tentativas da esquerda de estabelecer a hegemonia política de forma unitária sobre o conjunto do movimento" (CASTELLS, 1986, p. 291).

Quando a esquerda ainda estava unida, no começo do governo Allende, os pobladores participaram massivamente da arena política com bandeiras comuns, multiplicando sua capacidade para produzir um novo sistema urbano. Contrariamente ao que pensava em $A$ Questão Urbana, é esse momento o que expressou a maior potencialidade do Movimento de Pobladores como movimento de massas e movimento social; porém, o Movimento de Pobladores teria sumido na polarização da luta política posterior.

$\mathrm{O}$ que caracterizaria os pobladores seria sua heteronomia. Ou seja, a capacidade de agentes externos de definirem a orientação do próprio movimento seria ao mesmo tempo sua principal 
fraqueza, pois os faria extremamente dependentes da particularidade das situações políticas que lhes corresponderia enfrentar como movimento. Tal como sintetizou Castells (1986, p. 296):

A heteronomia social dos pobladores, sua localização, sua ênfase na comunidade e a territorialidade, não são sintomas de um tipo especial de personalidade psicológica. Sua dependência do sistema político se encontra no próprio miolo de sua condição social. Sua falta de identidade como movimento social é a expressão direta de sua experiência, de sua incapacidade de encontrar vias de protesto alheias à proteção das forças políticas existentes. Ao perpetuar sua relação com o Estado e ampliar seus assentamentos a um ritmo crescente, os invasores ilegais vêm a ser a força impulsora na produção social da forma urbana denominada cidade dependente; uma cidade onde a maioria dos trabalhadores devem tomar sob sua responsabilidade uma proporção substancial da reprodução de sua própria força de trabalho; onde, para isso, o Estado tem que obviar suas próprias regras institucionais; onde, para conseguir essa tolerância, os pobladores devem achar protetores poderosos que os acolham, e onde a forma urbana resultante degenera numa constelação inarticulada de funções e lugares, relacionados mediante redes invisíveis com os mecanismos subjacentes dessa dinâmica urbana, desde a tecnologia do transporte imposta pelas multinacionais, até as pautas de invasão de terrenos programadas por urbanizações ilegais. 